\title{
DETERMINANTS OF BANK SOCIAL RESPONSIBILITY: CASE OF CROATIA
}

\author{
Ana Ivanisevic Hernaus, Alen Stojanovic
}

\section{Introduction}

Recent financial turmoil, uncertain and unstable world and increasing public pressure have put financial sector and its responsibilities under great scrutiny. This has led to putting more emphasis on social responsibility of financial institutions, primarily banks, due to a powerful and influential position they have. Indeed, bank managers are becoming more concerned with social responsibility [72], resulting in a widespread adoption of social responsibility by the global banking community [64].

The considerable emphasis placed nowadays on the societal role of business is in accordance with the spreading belief that measures of company success must go beyond profit and should also relate to the needs of stakeholders and society at large [68]. Caroll [12] anticipated that the social aspect of company's responsibility in the $21^{\text {st }}$ century will be more important than ever. Corporate social responsibility (CSR) is becoming the defining business issue of our time, affecting corporate profits and credibility, as well as personal security and sustainability of the global economy (see [18], cited in [12]). From a perspective of companies, social responsibility has become a powerful tool of gaining more favourable attitudes among their stakeholders [73], resulting in various benefits for companies themselves.

Business ethics and community support play an important role in various industries, including the banking sector [25]. This role is emphasized even more considering the fact that bank activities have significant and broad, not only economic, but also social implications. Social responsibility of banks and other financial institutions has already been recognised as necessary (e.g. [23], [10], [76], [81], [15]). The matter that arises is how the banking sector has and will continue to evolve in this respect. However, social responsibility of banks has been dominantly investigated in developed countries, with lack of research in less developed and transition countries. While CSR is relatively well established in Western Europe, USA and Australia [5], [69], limited understanding of CSR and only recent adoption of CSR practices characterise less developed countries. Although many authors point out on the importance of CSR research in developing country contexts ([5], [32], [58], [59]), there is a lack of empirical findings. This study extends research in Central and Eastern European (CEE) context, contributing to scarce literature on CSR in these countries (e.g. [42], [40], [47], [94]). It presents a break-through attempt to investigate determinants of CSR in Croatian banking industry.

In spite of relevance and timeliness of the issue, research in Croatia has been lagging behind recent literature on this topic, with the exception of only few notable studies. Some of them provide a conceptual framework of social responsibility (e.g. [89]), while most of the studies conducted focus on specific CSR issues (e.g. [50], [37], [24]). Some studies investigate social responsibility of companies from different industries ([90], [34], [94]), and social responsibility of the banking industry in particular has been somewhat addressed by Leko and Stojanovic [56], [57], Dujmovic, et al. [28] and Kundid and Rogosic [52], however there still exists a research gap. Therefore, the purpose of this paper is to assess social responsibility of Croatian banks, and moreover, to investigate its relation with selected factors in the banking industry.

This study links social responsibility to characteristic factors of individual banks and of the environment in which they operate, i.e. specific Croatian context. In particular, the emphasis is put on factors of bank size, 
ownership status and financial performance at the individual level, linking social responsibility to individual bank characteristics, while at the industry level of Croatian banking sector we critically reflect on bank social responsibility by focusing on the structure of granted loans.

The approach taken differs from most previous studies because the research is conducted on both micro and macro level, which potentially offers a broader understanding of social responsibility in the banking industry. Our aim is to highlight holistic perspective of bank social responsibility in a particular CEE country. Research findings will provide additional understanding of what social responsibility in banking means, which factors does it relate to, and how it works in a specific environment.

This paper is structured as follows: to start with, the next part provides a brief literature review about the concept of social responsibility in the banking industry. Then, hypotheses are introduced, followed by research methodology after that. To follow, research findings are presented. Finally, the implications of our findings as well as practical standpoints are discussed, while the paper is concluded with a presentation of the limitations and some future research proposals.

\section{Social Responsibility in the Banking Industry}

CSR has never been more prominent on the corporate agenda than it is today ([85], cited in [41]). It has become a focal point of policy makers and the public, who demand that companies assume responsibility towards society, the environment, or the stakeholders in general [77]. Companies do have social responsibility and are not protected by limited liability from the consequences of their actions (see [38]). They have the responsibility for their impacts on society, comprising various environmental, social and economic obligations.

As far as it regards the banking industry, social responsibility practices have been embraced by the global banking community, evidenced by banks pouring millions of dollars into this purpose, signing international agreements that support socially responsible development [64] and increasingly reporting on their social responsibility. Banks are beginning to recognize that they do have a social responsibility to fulfil [6] and that only socially responsible banking is sustainable in the long run.

A number of factors have contributed to a more socially responsible orientation in banking. The increased economic and public pressure has forced banks to analyse their role in society and their contribution to obtaining more sustainable development [23]. In particular, the recent economic crisis and its social consequences have to some extent damaged consumer confidence and the level of trust in financial institutions. Demonstrating (and not only claiming) responsibility towards society is crucial for regaining trust, and banks are increasingly recognizing it. Furthermore, banks themselves are becoming increasingly aware of the risk associated with financing environmentally or socially sensitive projects. Therefore, in their lending activities they analyse how to fairly balance the risk and interests of various parties affected by their business.

A variety of industry trends and factors are also leading to intensifying the move toward socially responsible banking. The marketplace in which banks operate today demands new solutions and service offerings. Some of these can be delivered through socially responsible products, where recently much of the focus has been put on environmentally-oriented products. The pressure is put on major international banks to find new areas for growth. Other factors, such as consolidation and heightened competition in traditional markets, and technology innovations in banking products and processes, have been contributing as well.

Due to the nature of their activities and their size, bank social responsibility is expected to be more complex in comparison to other companies. A bank's responsibility extends to government, customers, shareholders, employees and the community [38]. Banks have a key role in government's aim of stewardship of the economy. As the most important financiers they uniquely perform functions of collecting deposits from wider public, granting loans, and running the payment system simultaneously. Additionally, they must take care of the ethical aspects of customer relationships, as people's assets are at stake [25]. Banks are answerable to their shareholders because they have invested their money in the business, are entitled to see it protected and rewarded by a fair return, and they also want to see their institution behaving in an ethically satisfactory 
fashion. Banks depend on people to run their business and to reflect their ethical standards, who have to know what is expected of them. Finally, through their business activities banks invest in the well-being of the communities they serve and their everyday decisions have a long term impact on those communities [38].

The advantages and disadvantages of social responsibility in the banking industry have been argued at length in previous research. Numerous publications have shown that being socially responsible can benefit banks substantially [82]. However, as CSR is impossible to measure directly, it was largely measured and assessed through corporate social performance (CSP). CSP is a multidimensional construct that measures the extent to which firms are acting (or not acting) in a socially responsible manner [26] and therefore it is used as a means to assess CSR policies and practices [80]. Various CSP measures are used, from one-dimensional (e.g. environmental pollution, corporate philanthropy) to multidimensional measures, i.e. indices of various CSR indicators such as KLD index or Fortune ratings data, as well as questionnaire based surveys. Content analysis of corporate disclosures has been also used in a number of academic studies (e.g. [1], [97], [32], [65], [91]).

From banks'point of view, social responsibility in its comprehensive understanding is the way of creating long-term value. It enables banks to recognize business opportunities and to manage risk more efficiently. It improves their reputation and branding, by influencing trust and customer perceptions (e.g. [73], [66]). Awareness of responsibility towards society and environment guarantees compliance with government regulations. Finally, it offers vast potential to improve and develop banks' own services, e.g. in fast-growing areas of sustainable energy, cleaner production, biodiversity conservation and banking services to low-income and underserved groups [43].

\section{Research Goal and Hypotheses}

The aim of the research is to assess to what extent are Croatian banks socially responsible and to investigate several key factors that potentially relate to their social responsibility. In order to achieve the research goal, four hypotheses are proposed. First three hypotheses focus on determining the relation between bank social responsibility and its individual factors, in order to discover which banks are more likely to be socially responsible. In particular, we focus on factors of bank size, ownership status and financial performance. While factors of size and financial performance have already been set as important and investigated in previous research on social responsibility, we find the factor of ownership status interesting, taking into consideration specific ownership structure of Croatian banking sector. Fourth hypothesis strives towards testing the relation of social responsibility and the structure of granted loans in Croatian banking sector, at the industry level. The reasoning behind including the factor of the loan structure in the analysis is that it is potentially very indicative of industry's social (ir)responsibility, because some important conclusions can be drawn from the focus of bank lending activity.

Among various bank-level attributes that are likely to be related to its social responsibility, one of the key issues is firm size, identified as both vital and relatively unexamined [59], [97]. Majority of existing literature indicates a positive link between firm size and level of social responsibility (e.g. [87], [14], [67], [88], [54]), and only some refers specifically to the banking industry (e.g. [81], [65]).

In general, larger firms are associated with more resources found to positively affect their CSR commitment [96], [45]. They also tend to be more visible, implying facing more pressures and higher level of attention from the general public (see [92]), to participate in voluntary programmes (e.g. [7]) and make donations (e.g. [2]). Larger organisations may also have more advanced internal systems for dealing with the management of issues, leading to greater responsiveness to social issues as well ([8], cited in [92]). Because of numerous external and internal reasons, a positive relation between bank size and social responsibility is expected. The question arises whether this is also true in Croatian case. The point of view taken is that larger banks have more resources to train employees about social and environmental issues, to invest in assessment and technological solutions to minimize environmental impact and protect worker safety, and to implement relevant social and environmental management procedures. Larger banks have also more responsibility to behave responsibly due to their visibility 
and brand image. They will disclose more information on social responsibility than smaller banks [39]. We adopt this view and based on it we present our first hypothesis:

$\mathrm{H}_{1}$ : Bank size and social responsibility are positively related.

Although numerous studies have recently been published examining determinants of CSR, a relatively small number of them consider ownership as an independent variable. Most of them examine relations between social responsibility and institutional ownership, managerial ownership, ownership structure dispersion or institutional investor types (e.g. [93], [16], [99], [36], [45], [59], [48]). However, very few take into consideration ownership status. In this regard Lee [55] focuses on public and private ownership status, while $Q u$ [74] and Oh, et al. [69] introduce a variable of foreign ownership. Qu [74] assumes that the effect does exist, while research results of Oh et al. [69] indicate a significant, positive relationship between foreign ownership and CSR, suggesting that different owners may also have different orientations and preferences regarding the firm's CSR. This research gap calls for further research on the relationship between different status of ownership and firm's social responsibility.

In spite of the fact that existing literature indicates that foreign ownership is associated with sustainability [51] and with higher level of CSR, Oh et al. [69] clearly indicate that all foreign investors are not always in favour of CSR. However, we can agree with Hinson et al. [39] that international banks are expected to disclose more of their social responsibility information than local banks, due to their international presence and image, due to being subject to international conventions, as well as to regulations that make their disclosures more mandatory. This is further reinforced by the nature of their activities, or internationalization, which requires them to communicate such responsibilities to society [9].

In Croatia, almost $50 \%$ of banks in terms of their number are foreign-owned, and in terms of total banking industry assets, more than $90 \%$ is in foreign ownership. Croatian banks which are owned by large international bank groups are expected to disclose more of their socially responsible practices and in that respect to be more socially responsible than local banks. This is due not only to mentioned reasons, but also to a know-how they receive from their foreign parent companies, which already proved to be far more advanced in demonstrating their social responsibility than banks operating only on Croatian market. In this context we stipulate our second hypothesis as follows:

$\mathrm{H}_{2}$ : Foreign-owned banks are characterized by higher levels of social responsibility in comparison to domestically owned banks.

A major stream of research has resulted from efforts to understand the relationship between social performance and financial performance that exists for companies [3], resulting in positive (e.g. [96], [79], [94]), negative (e.g. [44], [46], [61]) and mixed evidence (e.g. [17], [16], [4]). Most of the studies of the banking industry document a positive link between these two constructs (e.g. [84], [42], [81], [65]).

The relationship between corporate social and financial performance remains one of the most attractive research topics [35]. That this collective research is large and important is evidenced in part by several major studies aimed at reviewing and analyzing the results of this accumulating research (e.g. [71], [62], [95], [70]). Besides the importance of empirical investigations of this relationship, Callan and Thomas [11] strongly emphasize its timeliness, because today, perhaps more than ever, firms are expected to dedicate resources to socially responsible activities.

Undoubtedly, a growing body of empirical evidence suggests that corporate social and financial performance are positively related. Despite a large and growing literature on CSR, there is very little evidence of firms actually sacrificing profits in the social interest [75]. And this is particularly true for the banking industry. In order to determine the existing social responsibility of Croatian banks, we test the following hypothesis by approximating financial performance with profitability:

$\mathrm{H}_{3}$ : Bank profitability and social responsibility are positively related.

Finally, a more complete understanding of bank social responsibility can be obtained by putting it into specific context. This is possible by taking into consideration characteristic 
factors of Croatian banking industry, where we particularly focus on dedicated structure of granted loans. Specific structure of granted bank loans is reflected in a relatively high share of non-productive loans for final consumption in total granted loans for the most important institutional sector, i.e. households.

As Snoy [86] argued, ethical issues that financial intermediaries, especially commercial banks, in the international sphere face are to whom does one lend and for what purpose does one lend. Issues in Croatian banking sector, due to a high percentage share of foreign ownership, can be much associated with issues of international banking. In their international loans, banks frequently and legitimately aim at supporting national exports of equipments and engineering services. However, this does not exempt them from responsibility on the part of the borrowing country to import these goods and services, neither on the part of final consumers, i.e. bank customers to buy oversized financial services poorly adapted to local conditions.

While most of the academic studies focus on other determinants of social responsibility such as profitability, size or ownership (e.g. [53]), there is a great lack of literature which would relate the structure of granted loans to social responsibility of a bank. The reason for this might be the fact that most of the studies on CSR in the banking industry were conducted in the most developed countries, whose banking systems do not face such issues. For example, banks in CEE countries are characterised by a relatively larger share of foreign ownership in comparison to most developed countries, which in the Central Europe (CE) sub-region stands, on average, at $75 \%$ and in the Southeastern Europe (SEE) sub-region at a very high $85 \%$ of total banking sector assets [27]. So certain issues occur exactly now, when studies on CSR in less developed and transition countries have emerged and consequently additional, specific factors gain on relevance, such as, for example, the share of loans for final consumption in total bank loans granted to institutional sector of households. Taking into consideration all mentioned above, we recognize this factor as important and we relate it to bank social responsibility. As the granted loan structure in Croatia has been extremely unfavourable for a number of years, because of its orientation on personal consumption, while largely neglecting production and development, we propose the following hypothesis:

$\mathrm{H}_{4}$ : Share of loans for final consumption in total bank loans granted to households is negatively related to social responsibility in the banking industry.

\section{Research Methodology}

This part describes the research done at two different levels, data collection on bank social responsibility, how the CSP measure is calculated and research methods used to test hypotheses.

Due to a multi-level nature of the planned research, we have to clearly determine two different levels of analysis - individual and industry. In order to test the first three hypotheses, we need to address individual bank social responsibility. The forth hypothesis is related to the aggregate, banking industry social responsibility in a specific Croatian context. It is focused on the structure of granted loans, where the euro area average is used as a benchmark.

As reporting on social responsibility is not yet standardized, individual-level data of banks was collected during October 2011 by detailed insight in all publicly available information and documents on banks' web sites such as bank's sustainability, CSR or social reports, reports on progress, periodical reports on performance, codes of conduct and other web-based information, as well as information from national (Croatian National Bank, Croatian Banking Association, Croatian Business Council for Sustainable Development, Croatian Banking and Finance Employees Trade Union) and international organizations and NGOs (Global Compact). This method of data collection is justified because nowadays the internet is used as a medium for corporate information disclosure to the public [39]. Necessary additional information was collected via telephone interviews with bank representatives. Content analysis is used to measure the level of social responsibility in accordance with presented framework. Defined as a technique for gathering data that consists of codifying qualitative information in anecdotal and literary form into categories in order to derive quantitative scales of varying levels of complexity [1], it is found to be the appropriate method for identifying themes in the raw data 
[13]. At the banking industry level, the main source of information were publications issued by the Croatian National Bank.

In order to assess social responsibility of individual banks, we evaluate banks with respect to various indicators, enabling a holistic stakeholder approach, evident in recent developments in CSR practice [63]. The framework for assessing bank social responsibility is derived and adapted from previous research conducted by CuestaGonzalez, et al. [23] and Scholtens [81]. The main reason why these studies are taken as a reference point is that their methodology, contrary to some other available approaches, is transparent and easily measurable.

There are five groups of indicators: 1) sustainability reporting and networking, 2) corporate governance, 3) environmental management, 4) responsible financial products and 5) stakeholder issues. These groups reflect different aspects of social responsibility and altogether provide a comprehensive view of bank social responsibility.

By reporting and networking, which might also require compliance with certain standards on reporting (e.g. UN Global Compact), we conclude that a bank commits itself to socially responsible behaviour. Corporate governance gives an indication of policies and procedures promoted by the bank and communicated to all employees. Transparency about environmental performance allows us to assess how a bank operates in this respect [81], analysed through indicators of environmental risk management in lending policy and exclusion of specific sectors in bank financing activities (e.g. production causing ecological damages). The supply and development of "green" or socially responsible products is another means by which a bank can signal its commitment to social responsibility (see [81]). Finally, stakeholder issues comprising relationships with employees and the community reflect social conduct of a bank, both internally and externally.

We made certain adaptations to CuestaGonzalez et al. [23] and Scholtens' [81] assessment framework. On the basis of interviews with subject matter experts, we selected 18 indicators relevant for describing socially responsible practices of Croatian banks. Some of the original indicators are not even available in banks' published documents, as social awareness of Croatian banks is still in the early stage of development. In order to test the validity of interviews' results, preliminary content analysis of banks' publications was conducted. It confirmed the selected 18 indicators, which were then analysed for each bank. Table 1 shows which indicators are used to assess individual bank social responsibility.

\section{Tab. 1: Bank social responsibility framework - Part 1}

\begin{tabular}{l|l|l}
\multicolumn{1}{c|}{ Group } & \multicolumn{1}{c|}{ Indicator } & \multicolumn{1}{c}{ Operationalization } \\
\hline $\begin{array}{l}\text { Sustainability reporting and } \\
\text { networking }\end{array}$ & $\begin{array}{l}1 \text { Sustainability report / CSR report / } \\
\text { Social report }\end{array}$ & Yes (1) or No (0) \\
\hline & 2 Global Reporting Initiative & Adopted (Yes/No) \\
\hline & 3 UN Global Compact Croatia & Adopted (Yes/No) \\
\hline & $4 \begin{array}{l}\text { Croatian Business Council for } \\
\text { Sustainable Development }\end{array}$ & Member (Yes/No) \\
\hline Corporate governance & 5 Croatian Banking Association & Member (Yes/No) \\
\hline & 6 CSR Index & Participant (Yes/No) \\
\hline & 7 Code of Ethics / Code od Conduct & Adopted (Yes/No) \\
\hline Environmental management & 8 Code of Corporate Governance & Adopted (Yes/No) \\
\hline & 9 Diversity & Women on board (Yes/No) \\
\hline $\begin{array}{l}\text { Responsible financial } \\
\text { products }\end{array}$ & 11 Exclusion of specific sectors & Yes/No \\
\hline
\end{tabular}


Tab. 1: Bank social responsibility framework - Part 2

\begin{tabular}{l|l|l}
\multicolumn{1}{c|}{ Group } & \multicolumn{1}{c|}{ Indicator } & \multicolumn{1}{c}{ Operationalization } \\
\hline & $\begin{array}{l}13 \text { Sustainability products („Green } \\
\text { loans“, „Energy efficiency loans“) }\end{array}$ & Yes/No \\
\hline Stakeholder issues & 14 Training and education & Yes/No \\
\hline Employee issues & 15 Trade unions & Activities of CBFETU (Yes/No) \\
\hline & 16 Feedback from employees & $\begin{array}{l}\text { Anonimous, including all } \\
\text { employees (Yes/No) }\end{array}$ \\
\hline $\begin{array}{l}\text { Involvement in the community } \\
\text { and commitement to } \\
\text { charitable work }\end{array}$ & 17 Sponsoring and donations & Yes/No \\
\hline & $18 \begin{array}{l}\text { Croatian Banking Association } \\
\text { workshops }\end{array}$ & Participant (Yes/No) \\
\hline
\end{tabular}

CSR Index = a project for assessment of Croatian companies' social responsibility, initiated by Croatian Chamber of Economy and Croatian Business Council for Sustainable Development, where a company's social responsibility is assessed according to methodology of UK's leading benchmark for corporate responsibility - Business in the Community Index; CBFETU = Croatian Banking and Finance Employees Trade Union

Source: Adopted from Cuesta-Gonzalez, et al. [23] and Scholtens [81]

Operationalization of the indicators is the following: if the bank performs or complies, it receives a positive score (1), otherwise zero (0). Such methodology is used in other academic studies as well (e.g. [81], [49], [78]). When banks do not report to be active with respect to some issue, we assume they are not, because it is exactly the transparency about social and environmental performance that allows us to assess how a bank operates in this respect (see [81]). The reasoning behind this is that it is becoming clear there ought to be a transparent and verifiable commitment to adoption of socially responsible practices. Generally, a principle of transparency is a constituent part of ethics applied in management and in economic decision-making [83]. And this is accomplished by explicit reference to social responsibility work banks are engaged in via reporting and publishing web-based information [29]. Communicating activities and results is especially important for banks, because their business depends on their credibility, and on the trust their stakeholders have in them [43]. In other words, clear, open and thorough communication is an integral part of a bank social responsibility.

The developed framework is applied to a population of 32 Croatian banks. As these banks make the whole Croatian banking sector, they are the best possible representation of a banking industry in a particular country. Six large banks, three medium-sized and twentythree small banks are included in the study. Large bank in Croatia is a bank with individual assets larger than $5 \%$ of total banking industry assets, medium bank is a bank with individual assets larger than $1 \%$ and smaller than $5 \%$ of total banking industry assets, and small bank is a bank with individual assets smaller than $1 \%$ of total banking industry assets (amounting to EUR 53.00 billion in 2010). Fifteen of the banks are in foreign, while seventeen are in domestic ownership. Social responsibility of the observed banks is assessed and empirically related firstly to individual, bank-level factors (size, ownership status and financial performance) by using correlation analysis, and then to industrylevel factor (dedicated granted loan structure) qualitatively.

\section{Research Findings}

Some general conclusions that can be drawn from descriptive statistics (see Tab. 2) are that Croatian banks accomplish the highest scores of social responsibility in corporate governance (relative average score of $53.1 \%$ ) and stakeholder issues (51.3\%) among all groups of indicators. Introducing 
responsible financial products $(12.5 \%)$ is least common among them. Possible explanation for this could be that the banks have already recognized potential materiality of certain social, environmental and governance issues, while they still do not use, at first sight less obvious, benefits arising from other issues. For example, benefits from sustainability reporting and networking may arise in a medium-to longterm, or, the banks are simply still not aware of a necessary expansion of financial products' offer, imposed not only by new industry trends but also by regulation (i.e. regulation regarding environment protection and energy efficiency).

\section{Tab. 2: Individual bank social responsibility results}

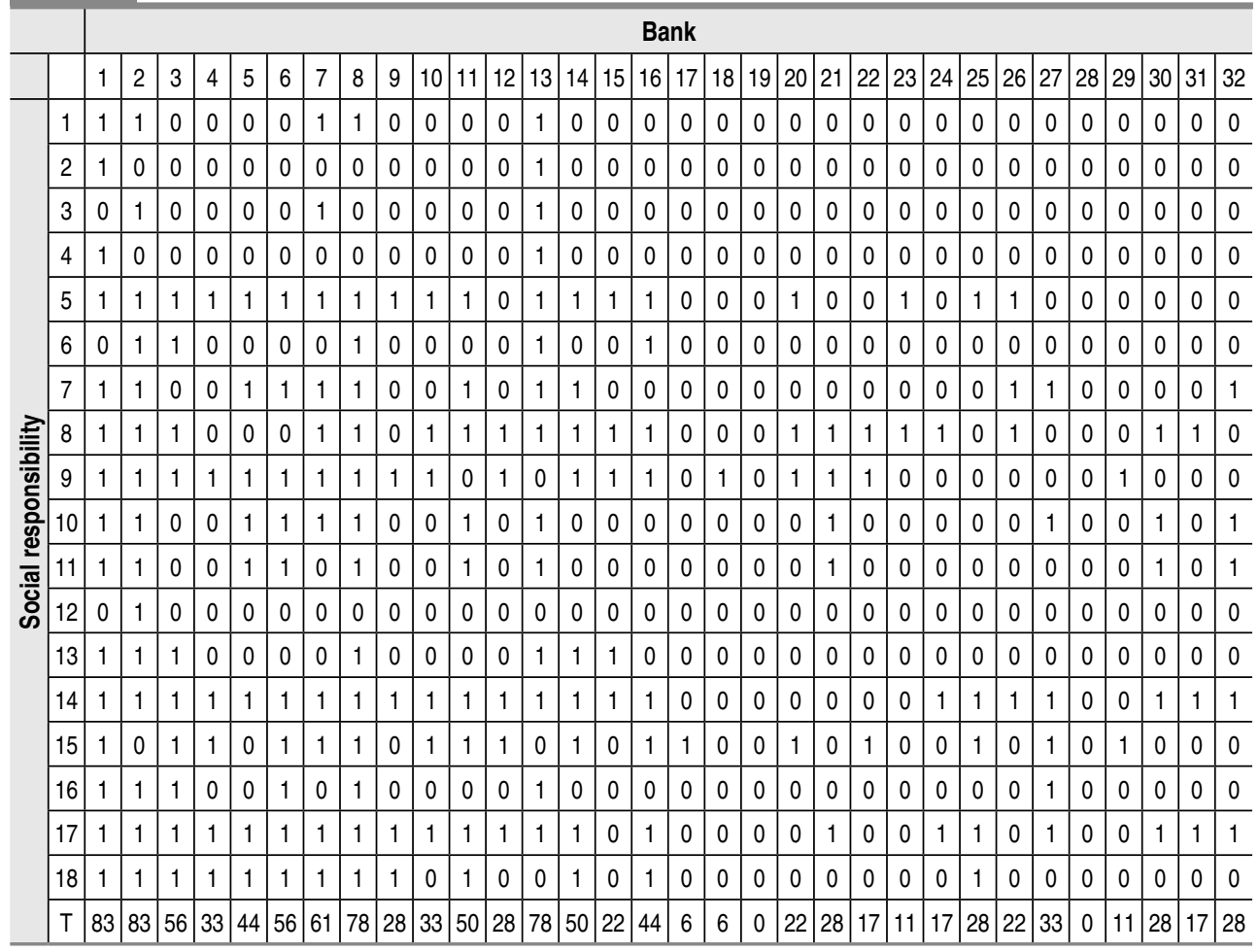

Social responsibility: number relates to indicator defined in Table 1; Bank: number relates to each of the 32 banks; $T$ = total score (percentage), calculated as a relative number of indicators on which a bank scores positive, e.g. the bank assigned number 1 receives a score of $83 \%$ because $T=15 / 18=0.83$.

Source: authors

Next, the nature of relation between banklevel factors and its social responsibility was investigated by using correlation analysis. Table 3 shows correlation coefficients $(\rho)$ of social responsibility of Croatian banks and factors of size, ownership and profitability. Not surprisingly, our research findings support the first hypothesis as it is clear that a high positive correlation between bank size and social responsibility is established $(\rho=.640, p=.000$, $\mathrm{N}=32$ ), leading to a conclusion that larger banks, in terms of their assets, are associated with higher levels of social responsibility.

A more detailed analysis shows that medium-sized banks closely follow large banks, and in some aspects of social responsibility, like sustainability reporting and networking and corporate governance, even slightly 
surpass them. On the other hand, small banks are evidently lagging behind although their relatively lower average scores in certain aspects of social responsibility can be reasonably expected. For instance, small banks in their everyday business, in comparison to larger banks, do not face challenges of financing large, environmentally or socially sensitive projects. This may explain their average score in environmental management of only $23.9 \%$. Furthermore, they are oriented on retail business and serving local community, primarily by financing consumer loans and liquidity of small and medium enterprises. Therefore, the structure of their offer is different from the one at larger banks, what possibly explains their average score of only $6.5 \%$ for responsible financial products. However, their bad performance in other aspects of social responsibility, indicated by low average scores in other groups of indicators, cannot be so easily justified.

Furthermore, ownership status and social responsibility of observed banks are fairly correlated $(\rho=-.480, p=.005, N=32)$. (In order to quantitatively analyse variable ownership status, foreign-owned banks were assigned generic number 1 , banks in domestic private ownership number 2, and banks in domestic public ownership number 3.) The medium and negative correlation between these variables points out that foreign-owned banks operating in Croatia in terms of their levels of social responsibility are in advance of banks owned by domestic parties. This is in accordance with the second hypothesis, proposing that foreignowned banks are characterized by higher levels of social responsibility in comparison to domestically owned banks.

Results of an in-depth analysis indicate that foreign-owned banks, with their average score of $48.9 \%$, perform better than domestically owned banks $(21.9 \%)$ in all aspects of social responsibility. Moreover, a partial analysis of the two groups of domestically owned banks was conducted, differentiating between those owned by private parties and those owned by the government. This analysis shows that banks in domestic private ownership (average score of only $20.4 \%$ ), with the only exception of responsible financial products offer, lag behind their domestic government-owned counterparts, indicating that the government, as a bank owner, is relatively more socially responsible in comparison to private parties at the same function. However, as far as it regards banks in domestic government ownership, one has to take into consideration that there are only two such banks in the sample, what makes social performance of these specific banks $(33.3 \%)$ potentially hardly generalisable in other contexts. Therefore, it is more advisable to observe them as a specific group.

Finally, the findings indicate a very weak and positive correlation between bank profitability and social responsibility, meaning that there is little or almost no association between bank profitability and its level of social responsibility. However, the results are not statistically significant, so they cannot be generalized. Weak and non-significant correlation leads us to reject the third hypothesis, meaning that there is no empirical evidence that bank financial and social performance are positively related.

\begin{tabular}{|c|c|c|c|c|c|}
\hline $\begin{array}{l}\text { Correlat } \\
\text { factors }\end{array}$ & coefficients & for level of $b$ & social res & Isibility ar & lected bank \\
\hline & $\begin{array}{c}\text { Social } \\
\text { responsibility }\end{array}$ & Size (Assets) & $\begin{array}{l}\text { Ownership } \\
\text { status }\end{array}$ & $\begin{array}{c}\text { Profitability } \\
\text { (ROA) }\end{array}$ & $\begin{array}{l}\text { Profitability } \\
\text { (ROE) }\end{array}$ \\
\hline Social responsibility & 1 & & & & \\
\hline Size (Assets) & $.640^{\star \star}$ & 1 & & & \\
\hline Ownership status & $-.480^{\star \star}$ & $-.410^{\star}$ & 1 & & \\
\hline Profitability (ROA) & .228 & .340 & -.121 & 1 & \\
\hline Profitability (ROE) & .218 & .289 & -.186 & $.923^{*}$ & 1 \\
\hline
\end{tabular}

$\mathrm{ROA}=$ Return on assets; $\mathrm{ROE}=$ Return on equity

${ }^{\star \star}$ Correlation is significant at the 0.01 level (2-tailed).

${ }^{\star}$ Correlation is significant at the 0.05 level (2-tailed). 
To analyse bank social responsibility at the industry level, we observe specific context in which the banks operate. As far as it regards the granted loan structure in Croatian banking industry, statistical data clearly indicate an unfavourable dedicated structure from the perspective of country's economic and sustainable development, and consequently also social development. One comes to alarming conclusions when analysing dedicated structure of loans granted to the largest institutional sector - households, receiving a major share $(46.2 \%)$ of total bank loans. The most important financial liability of households should be home mortgages, as the most important households assets is home equity. However, analysis indicates a lower share of home mortgages (45.6\%) compared to euro area average, where they represent more than two thirds of total loans granted to households (see Tab. 4). In Croatia, an extremely high share $(54.4 \%)$ belongs to dedicated and nondedicated loans for financing final consumption [22]. This share was higher and therefore even more unfavourable several years ago $(59.8 \%$ in 2007) [22], but although nowadays consumer enthusiasm is evidently affected by financial crisis, it is still very high. This makes granted loan structure extremely negative, and much different from the one in euro area countries, but very much alike the structure in other CEE countries where, in this respect, Croatia is no exception. Looking from a wider perspective would indicate that other factors, besides bank owners' strategies, have also contributed to such an unfavourable granted loan structure (e.g. economic cycle, bank competition, disorder on Croatian real estate market, factual situation in particular industries).

\section{Tab. 4: Dedicated structure of bank loans to households: a comparison of the euro
area and Croatia}

\begin{tabular}{l|c|c|c|c|c|c|c|c|c} 
& \multicolumn{2}{|c|}{2007} & $\mathbf{2 0 0 8}$ & \multicolumn{2}{c|}{2009} & \multicolumn{2}{c}{2010} \\
\cline { 2 - 9 } & Value & Share & Value & Share & Value & Share & Value & Share \\
\hline & \multicolumn{7}{c}{ euro area (value in bln EUR, share in \%) } \\
\hline Home mortgages & 3,425 & 71.5 & 3,488 & 71.4 & 3,546 & 71.6 & 3,701 & 71.7 \\
\hline Consumer loans & 616 & 12.9 & 631 & 12.9 & 631 & 12.7 & 639 & 12.4 \\
\hline Other loans* & 747 & 15.6 & 764 & 15.7 & 774 & 15.6 & 819 & 15.9 \\
\hline & \multicolumn{7}{|c|}{ Croatia (value in min HRK, share in \%) } \\
\hline Home mortgages & 45,232 & 40.3 & 52,318 & 41.5 & 52,960 & 43.3 & 57,981 & 45.6 \\
\hline Car loans & 9,389 & 8.4 & 9,646 & 7.7 & 7,811 & 6.4 & 6,237 & 4.9 \\
\hline Credit card loans & 4,923 & 4.4 & 5,530 & 4.4 & 5,022 & 4.1 & 4,387 & 3.5 \\
\hline Other loans** & 52,821 & 47.0 & 58,429 & 46.4 & 56,403 & 46.2 & 58,531 & 46.0 \\
\hline
\end{tabular}

euro area: Monetary financial institutions (MFI) sector excluding the Eurosystem; Croatia: commercial banks

*loans granted for purposes such as debt consolidation, education, etc. [31]

${ }^{\star *}$ cash general purpose loans, overdraft facilities, non-dedicated mortgage loans and all other household loans [22]

Source: European Central Bank [30a, 30b], CROATIAN NATIONAL BANK [22].

Available savings in Croatia are evidently used for financing consumption and stimulating consumer mentality of households, just as in the case of companies, the same banks have been financing high profitable short-term loans and neglecting development. Unfavourable granted loan structure in Croatian banking industry can in no way be considered as supportive of social responsibility, because it lacks credit support to restructuring and development of Croatian economy. The analysis of dedicated loan structure indicates social irresponsibility of banks in Croatia, where they do materialize their interests, but at the same time behave completely differently compared to how they behave in their parent countries, and opposite to Croatian national interests. We therefore accept the fourth hypothesis, as we conclude 
that the share of loans for final consumption in total bank loans granted to households is negatively related to social responsibility in the banking industry.

\section{Discussion and Conclusion}

Research results bring forward some interesting points for discussion. They indicate that foreign owners have brought and implemented certain, higher level of social responsibility in Croatian banking industry. They have introduced the best practices from more advanced banking systems. However, the level of social responsibility is not as high as it could be, due to foreign-owners' motives, reflected through dedicated granted loan structure. Namely, the granted loan structure in Croatia, similarly to other CEE countries, has been extremely unfavourable for a number of years, reflecting the fact that primary interest of foreign owners differs from interest of domestic ones. This is true especially of the government, which is expected to be more oriented towards a development of local communities and towards economic and sustainable development of a country in general. If we take into consideration that more than $90 \%$ of total banking sector assets in Croatia is in foreign ownership, this reasoning seems obvious.

The study clearly shows that larger banks, in general, demonstrate higher levels of social responsibility. They are able to achieve higher levels due to having more resources, and they are in a way forced to comply or perform better due to being more visible. However, there are some outstanding exceptions among relatively small banks, which may possibly be explained by a high level of social awareness among their parent banks, pursuing the same socially responsible strategy in the whole bank group.

Furthermore, the results confirm bank size and ownership status as determinants of bank social responsibility, indicating that a bank's motivation and capacity to take on or to improve its social responsibility is related to these factors. At the banking industry level, orientation on financing final consumption has a significant influence on industry's social responsibility, which, in the case of Croatia, proved to be a hindering factor. In sum, through empirical analysis three out of four hypotheses were confirmed, proving that size, ownership status and share of loans for final consumption in total granted loans are significant determinants of bank social responsibility. Only third hypothesis was rejected, as the empirical analysis indicated a very weak association between bank profitability and social performance, leading to a conclusion that bank financial performance is not related to its social responsibility.

Conducted research has several limitations. Results identified are dependent on how well the measures operationalize the construct of social responsibility, as they are subject to limitations inherent in the measurement of corporate social performance. Futhermore, the analysis is focused only on compliance or performance of social responsibility, but does not aim at addressing the intensity by which the bank does so. It heavily relies on information provided by the institutions themselves, which might suffer from the self-reporting bias. We did not examine trustworthiness of available information as the primary intent of this research was to indicate compliance or performance among Croatian banks. However, in spite of mentioned research limitations, they are common and acceptable in this emerging and still underdeveloped research field (see [81]). Therefore, conducted analysis and obtained results provide an assessment of social responsibility among Croatian banks and its relation to specific factors in the banking industry, and they may serve as a basis for further development of socially responsible practices among Croatian banks.

These findings have very important implications for practitioners. They denote which banks are more likely to be socially responsible, and what is more, after considering pre-determined bank factors, in what aspects of social responsibility are these banks generally expected to be active. Findings also indicate that bank managers in Croatia are becoming aware of the importance of social responsibility, which can be recognized from existing socially responsible practices.

This study may be of use also to bank managers seeking to implement or improve socially responsible practices. Socially responsible loans can be obtained by focusing more on real needs of bank customers and by eliminating or at least decreasing predatory lending practices. Preferring and pushing loans for final consumption to households while neglecting demand for more vital purposes such as housing can in no way be considered as socially responsible. Moreover, meeting the needs of the community to a larger extent than 
present is possible and necessary not only in the retail segment, but also within corporate business. This would primarily imply providing crucial long-term credit support to creditworthy companies, needed for development and sustainability of economic activity, and not only running for more profitable short-term loans. It should be emphasized that a "shortterm" policy, however profitable it may be, is not socially responsible and definitely not sustainable. There are many different ways to lend money and what bank managers should be aware of is that ethical decisions and behaviour are not necessarily inconsistent with profitability. From the bank's point of view, improving its relation with community in the form of a more socially adapted loan structure may result in increasing existing customer trust, attracting new customers, and sustaining the brand name, which all may distinguish the bank from its competitors. These benefits that may arise from implementation of CSR policies and practices are in today's turbulent times more important than ever before for bank's survival and sustainability.

This paper also provides new insights into various socially responsible practices of Croatian banks and adds value to the existing literature. Therefore, it presents a useful reference point both for researchers and bank managers in their understanding of social responsibility in the banking industry, tested empirically on the whole banking industry in a particular country. It can serve as a model for further development of bank social responsibility in less developed and transition countries.

In order to confirm the study findings, there is a need for more extensive, confirmatory research on the relation of social responsibility and selected factors in the banking industry in the future. For further research we suggest including more variables in the analysis. What is more, investigating on the causal relationship between selected factors and social responsibility on the same sample of banks would be interesting and necessary. Results obtained in such a research could give a more transparent overview of a socially responsible banking or could potentially serve as an incentive for taking on socially responsible practices, depending on the results of the analysis.

Finally, as the issue of social responsibility is still rather new among Croatian banks, for now it was not possible to analyse development of Croatian banks' social responsibility through time. However, within a couple of years forward a planned longitudinal research would provide us with new insights. Therefore, we recommend it as an important and necessary guideline for future research.

\section{References}

[1] ABBOT, W.F., MONSEN, R.J. On the Measurement of Corporate Social Responsibility: Self-Reported Disclosures as a Method of Measuring Corporate Social Involvement. Academy of Management Journal. 1979, Vol. 22, No. 3, pp. 501-515. ISSN 00014273. DOI: $10.2307 / 255740$.

[2] ADAMS, M., HARDWICK, P. An analysis of corporate donations: United Kingdom evidence. Journal of Management Studies. 1998, Vol. 35, No. 5, pp. 641-654. ISSN 0022-2380. DOI: 10.1111/1467-6486.00113.

[3] ANDERSEN, M.L., OLSEN, L. Corporate social and financial performance: A canonical correlation analysis. Academy of Accounting and Financial Studies Journal. 2011, Vol. 15, No. 2, pp. 17-36. ISSN 1096-3685.

[4] BARON, D.P., HARJOTO, M.A., JO, H. The Economics and Politics of Corporate Social Performance. Business and Politics. 2011, Vol. 13, No. 2, pp.1-46. ISSN 1469-3569. DOI: 10.2202/1469-3569.1374.

[5] BELAL, A.R. A study of corporate social disclosures in Bangladesh. Managerial Auditing Journal. 2001, Vol. 16, No. 5, pp. 274-289. ISSN 0268-6902.DOI: 10.1108/02686900110392922. [6] BIHARI, S.C. Green banking - towards socially responsible banking in India. International Journal of Business Insights and Transformation. 2010, Vol. 4, No. 1, pp. 82-87. ISSN 0974-5874.

[7] BORCK, J., COGLIANESE, C., NASH, J. Why Do They Join? An Exploration of Business Participation in Voluntary Environmental Programs. In: Beyond Compliance: Business Decision Making and the US EPA's Performance Track Program. Regulatory Policy Program Report. Cambridge, MA: John F. Kennedy School of Government, Harvard University, 2006. RPP-10.

[8] BRAMMER, S., MILLINGTON, A. Firm Size, Organizational Visibility and Corporate Philanthropy: An Empirical Analysis. Business Ethics: A European Review. 2006, Vol. 15, No. 1, pp. 6-18. ISSN 0962-8770. DOI: 10.1111/j.14678608.2006.00424.x. 
[9] BRONN, P., BRONN, C. A reflective stakeholder approach: co-orientation as a basis for communication and learning. Journal of Communication Management. 2003, Vol. 7, No. 4, pp. 291-303. ISSN 1363-254X. DOI: 10.1108/13632540310807430.

[10] CALABRESE, A., LANCIONI, F. Analysis of Corporate Social Responsibility in the Service Sector: Does Exist a Strategic Path? Knowledge and Process Management. 2008, Vol. 15, No. 2, pp. 107-125. ISSN 1092-4604. DOI: $10.1002 / \mathrm{kpm} .303$.

[11] CALLAN, S.J., THOMAS, J.M. Corporate Financial Performance and Corporate Social Performance: An Update and Reinvestigation. Corporate Social Responsibility and Environmental Management. 2009, Vol. 16, No. 2, pp.61-78. ISSN 1535-3958. DOI: 10.1002/csr.182.

[12] CARROLL, A.B. Ethical challenges for business in the new millennium: corporate social responsibility and models of management morality. Business Ethics Quarterly. 2000, Vol. 10, No. 1, pp. 33-42. ISSN 1052-150X. DOI: $10.2307 / 3857692$.

[13] CAVANA, R.Y., DELAHAYE, B.H., SEKARAN, U. Applied Business Research: Qualitative and Quantitative Methods. 1st ed. Brisbane: John Wiley and Sons, 2001. ISBN 0471341266.

[14] CHIH, H.-L., CHIH, H.-H., CHEN, T.Y. On the Determinants of Corporate Social Responsibility: International Evidence on the Financial Industry. Journal of Business Ethics. 2010, Vol. 93, No. 1, pp. 115-135. ISSN 01674544. DOI: $10.1007 / \mathrm{s} 10551-009-0186-\mathrm{x}$.

[15] COELHO, M., FILIPE, J.A., FERREIRA, M.A.M. Environmental sustainability as a dimension of corporate social responsibility: The case of CGD - Caixy Geral Depositos/Portugal. International Journal of Academic Research. 2011, Vol. 3, No. 1, pp. 610-617. ISSN 2075-4124. [16] COFFEY, B.S., FRYXELL, G.E. Institutional Ownership of Stock and Dimensions of Corporate Social Performance: An Empirical Examination. Journal of Business Ethics. 1991, Vol. 10, No. 6, pp. 437-444. ISSN 0167-4544. DOI: $10.1007 / B F 00382826$.

[17] COCHRAN, P., WOOD, R.A. Corporate Social Responsibility and Financial Performance. Academy of Management Journal. 1984, Vol. 27, No. 1, pp. 42-56. ISSN 0001-4273. DOI: 10.2307/255956.

[18] COSTA, J.D. The Ethical Imperative: Why Moral Leadership is Good Business. Reading.
Mass: Perseus Books, 1998. ISBN 0738201308. [19] CROATIAN BANKING ASSOCIATION, CBA. Official data [online]. CBA, c2011 [cit. 2011-11-22]. Available from: http://www.hub.hr/. [20] CROATIAN BANKING AND FINANCE EMPLOYEES TRADE UNION, CBFETU. Official data [online]. CBFETU, c2011 [cit. 201111-22]. Available from: http://www.sbf.hr/.

[21] CROATIAN BUSINESS COUNCIL FOR SUSTAINABLE DEVELOPMENT, CBCSD. Official data [online]. CBCSD, c2011 [cit. 201111-22]. Available from: http://www.hrpsor.hr/.

[22] CROATIAN NATIONAL BANK, CNB. Bank Bulletin. Zagreb: Croatian National Bank, 2011. No. 22. ISSN 1333-1035.

[23] CUESTA-GONZALEZ, M., MUNOZTORREZ, M.J., FERNANDEZ-IZQUIERDO, M.A. Analysis of Social Performance in the Spanish Financial Industry Through Public Data. A Proposal. Journal of Business Ethics. 2006, Vol. 69, No. 3, pp. 289-304. ISSN 0167-4544. DOI: 10.1007/s10551-006-9091-8.

[24] DEBELJAK, J., KRKAC, K., BUSLJETA BANKS, I. Acquiring CSR practices: from deception to authenticity. Social Responsibility Journal. 2011, Vol. 7, No. 1, pp. 5-22. ISSN 17471117. DOI: $10.1108 / 17471111111114503$.

[25] DE LOS SALMONES, M., DEL, M.G., PEREZ, A., DEL BOSQUE, I.R. The social role of financial companies as a determinant of consumer behaviour. International Journal of Bank Marketing. 2009, Vol. 27, No. 6, pp. 467-483. ISSN 0265-2323. DOI: 10.1108/02652320910988339.

[26] DENNIS, B., D'INTINO, R.S., HOUGHTON, J.D., NECK, C.P., BOYLES, T. Corporate Social Performance: Creating Resources to Help Organizations Excel. Global Business and Organizational Excellence. 2008, Vol. 27, No. 2, pp. 26-41. ISSN 1932-2054. DOI: 10.1002/ joe.20192.

[27] DEUBER, G., SIKIMIC, J. CEE Banking Sector Report - Banking Sector Convergence 2.0 [online]. Vienna: Raiffeisen Bank International $A G$ and Raiffeisen Centrobank AG, c2011 [cit. 2011-11-22]. Raiffeisen Research. Available from: http:// www.rbinternational.com/eBusiness/services/ resources/media/677012584775275435677012584775275436 . 677251119927032833-7721043171202231791-9-DE.pdf.

[28] DUJMOVIC, M., SINKOVIC, D., VITASOVIC, A. Corporate social responsibility in the banking sector - Case study Croatia. In:TRIVUN, V., et al. 
Proceedings of the International Conference ICES 2010, "Economic Development Perspectives of SEE Region in Global Recession Context". Sarajevo: University of Sarajevo, School of Economics and Business, 2010. pp. 181. ISBN 978-9958-25-046-0.

[29] EUROPEAN BANKING FEDERATION, EBF. European banking sector best practices [online]. EBF, c2008 [cit. 2011-11-22]. Available from: http://bank-axess.com/PageFiles/10249/ CSR-sizereduced.pdf.

[30] EUROPEAN CENTRAL BANK. [30a] Monthly Bulletin 10/2009; [30b] Monthly Bulletin 10/2011. Frankfurt am Main: ECB, c2009; c2011. ISSN 1725-2822.

[31] EUROPEAN CENTRAL BANK. Glossary [online]. ECB, c2011 [cit. 2011-11-22]. Available from: http://www.ecb.europa.eu/home/glossary/ $\mathrm{html} /$ index.en.html.

[32] GAO, Y. Corporate Social Performance in China: Evidence from Large Companies. Journal of Business Ethics. 2009, Vol. 89, No. 1, pp. 23-35. ISSN 0167-4544. DOI: 10.1007/ s10551-008-9982-y.

[33] GLOBAL COMPACT CROATIA. Official data [online]. UNDP Global Compact, c2011 [cit. 2011-11-22]. Available from: http://www. drustvena-odgovornost.undp.hr/.

[34] GOLJA, T., KRSTINIC NIZIC, M. Corporate social responsibility in tourism - The most popular tourism destinations in Croatia: Comparative analysis. Management: Journal of Contemporary Management Issues. 2010, Vol. 15, No. 2, pp. 107-121. ISSN 1331-0194.

[35] GOND, J.-P., PALAZZO, G. The social construction of the positive link between corporate social and financial performance. In: Academy of Management Best Paper Proceedings [CD]. Academy of Management Annual Meeting, Anaheim, California: Academy of Management, 2008. pp. 1-6. ISSN 15438643.

[36] GRAVES, S.B., WADDOCK, S.A. Institutional owners and corporate social performance. Academy of Management Journal. 1994, Vol. 37, No. 4, pp. 1034-1046. ISSN 0001-4273. DOI: 10.2307/256611.

[37] GRBAC, B., LONCARIC, D. Ethics, social responsibility and business performance in a transition economy. EuroMed Journal of Business. 2009, Vol. 4, No. 2, pp. 143-158. ISSN 1450-2194.DOI: 10.1108/14502190910976501. [38] GREEN, C.F. Business Ethics in Banking. Journal of Business Ethics. 1989, Vol. 8, No. 8, pp. 631-634. ISSN 0167-4544. DOI: 10.1007/ BF00383031.

[39] HINSON, R., BOATENG, R., MADICHIE, N. Corporate social responsibility activity reportage on bank websites in Ghana. International Journal of Bank Marketing. 2010, Vol. 28, No. 7, pp. 498-518. ISSN 0265-2323. DOI: 10.1108/02652321011085176.

[40] HOREHÁJOVÁ, M., MARASOVÁ, J. The institutional factors of the corporate social responsibility development in the Central European countries. E+M Ekonomie a Management. 2008, Vol. 11, No. 2, pp. 58-64. ISSN 1212-3609.

[41] HUMPHREYS, M., BROWN, A.D. An Analysis of Corporate Social Responsibility at Credit Line. Journal of Business Ethics. 2008, Vol. 80, No. 3, pp. 403-418. ISSN 0167-4544. DOI: $10.1007 / \mathrm{s} 10551-007-9426-0$.

[42] IAMANDI, I.-E., CAGARIN, A.R., CHICIUDEAN, A., DRAGOI, M.C. Corporate Social Responsibility - Analysing Social and Financial Performance, The Case of Romania. European Research Studies. 2007, Vol. 11, Special Issue 3-4, pp. 19-30. ISSN 1108-2976. [43] INTERNATIONAL FINANCE CORPORATION. Banking on Sustainability: Financing Environmental and Social Opportunities in Emerging Markets [online]. Washington: IFC, c2007 [cit. 2011-11-22]. Available from: http://www. ifc.org/ifcext/enviro.nsf/AttachmentsByTitle/p_ BankingonSustainability/\$FILE/FINAL_IFC_ BankingOnSustainability_web.pdf.

[44] JAGGI, B., FREEDMAN, M. An examination of the impact of pollution performance on economic and market performance: pulp and paper firms. Journal of Business Finance \& Accounting. 1992, Vol. 19, No. 5, pp. 697713. ISSN 0306-686X. DOI: 10.1111/j.14685957.1992.tb00652.x.

[45] JOHNSON, R.A., GREENING, D.W. The effects of corporate governance and institutional ownership types on corporate social performance. Academy of Management Journal. 1999, Vol. 42, No. 5, pp. 564-576. ISSN 0001-4273. DOI: 10.2307/256977.

[46] JONES, S., VAN DER LAAN, S., FROST, G., LOFTUS, J. The Investment Performance of Socially Responsible Investment Funds in Australia. Journal of Business Ethics. 2008, Vol. 80 , No. 2, pp. 181-203. ISSN 0167-4544. DOI: 10.1007/s10551-007-9412-6.

[47] KAMINSKA-LABBE, R., BUCHELT, B. Corporate Social Performance in a Post-transition 
Context: The Case of Polish Firms. In: SUDER, G.G.S. International Business under Adversity: A Role in Corporate Responsibility, Conflict Prevention and Peace. Cheltenham, UK, Northampton, MA, USA: Edward Elgar, 2008. pp. 104-118. ISBN 978-1847203748.

[48] KANGARLUIE, S.J., BAYAZIDI, A. Corporate Governance Mechanisms And Corporate Social Responsibility (CSR): Evidence From Iran. Australian Journal of Basic and Applied Sciences. 2011, Vol. 5, No. 9, pp. 1591-1598. ISSN 1991-8178.

[49] KARAIBRAHIMOGLU, Y.Z. CSR in times of financial crisis. African Journal of Business Management. 2010, Vol. 4, No. 4, pp. 382-389. ISSN 1993-8233.

[50] KORICAN, M., JELAVIC, I. CSR, women and SMEs: the Croatian perspective. Social Responsibility Journal. 2008, Vol. 4, No. $1 / 2$, pp. 56-62. ISSN 1747-1117. DOI: 10.1108/17471110810856839.

[51] KRONBORG, D., THOMSEN, S. Foreign ownership and long-term survival. Strategic Management Journal. 2009, Vol. 30, No. 2, pp. 207-219. ISSN 0143-2095. DOI: 10.1002/ smj.732.

[52] KUNDID, A., ROGOSIC, A. Bank Online Reporting: Comparative Advantage, Formalism or Fashion? Global Business and Economics Anthology. 2011, Vol. 2, Iss. 2, pp. 500-518. ISSN 1553-1392.

[53] KUNTZ, E.C., KEDIA, B.L., WHITEFAEAD, C.J.Variations in Corporate Social Performance. California Management Review. 1980, Vol. 22, No. 4, pp. 30-36. ISSN 0008-1256. DOI: $10.2307 / 41164887$.

[54] KUZMA, J., KUZHABEKOVA, A. Nanotechnology, voluntary oversight, and corporate social performance: does company size matter? Journal of Nanoparticle Research. 2011, Vol. 13, No. 4, pp. 1499-1512. ISSN 13880764. DOI: $10.1007 / \mathrm{s} 11051-011-0235-0$.

[55] LEE, M.-D.P. Does Ownership Form Matter for Corporate Social Responsibility? A Longitudinal Comparison of Environmental Performance between Public, Private, and Jointventure Firms. Business and Society Review. 2009, Vol. 114, No. 4, pp. 435-456. ISSN 00453609. DOI: 10.1111/j.1467-8594.2009.00349.x. [56] LEKO, V., STOJANOVIC, A. Social Responsibility of Private Banks. In: RAJKOVIC, V., et al. Proceedings of the $26^{\text {th }}$ International Conference on Organizational Science Development-Creative Organization. Portoroz:
University of Maribor, Faculty of Organizational Sciences, 2007. pp. 976-983. ISBN 978-961232-200-7.

[57] LEKO, V., STOJANOVIC, A. Financijska iskljucenost (Financial exclusion). In: GULIN, D., et al. Proceedings of the $42^{\text {nd }}$ symposium of Croatian Association of Accountants and Financial Experts in Pula - Finance and accounting in the function of supporting Croatian economy. Pula: Croatian Association of Accountants and Financial Experts, 2007. pp. 123-134. ISBN 978-253-027-8.

[58] LI, S., FETSCHERIN, M., ALON, I., LATTEMANN, C., YEH, K. Corporate Social Responsibility in Emerging Markets. Management International Review. 2010, Vol. 50, No. 5, pp. 635-654. ISSN 0938-8249. DOI: 10.1007/s11575-010-0049-9.

[59] LI, W., ZHANG, R. Corporate Social Responsibility, Ownership Structure, and Political Interference: Evidence from China. Journal of Business Ethics. 2010, Vol. 96, No. 4, pp. 631-645. ISSN 0167-4544. DOI: 10.1007/ s10551-010-0488-z.

[60] MADDEN, K., SCAIFE, W., CRISSMAN, K. How and Why Small to Medium Size Enterprises (SMEs) Engage with Their Communities: An Australian Study. International Journal of NonProfit and Voluntary Sector Marketing. 2006, Vol. 11, No. 1, pp. 49-60. ISSN 1465-4520. DOI: 10.1002/nvsm.40.

[61] MAKNI, R., FRANCOEUR, C., BELLAVANCE, F. Causality Between Corporate Social Performance and Financial Performance: Evidence from Canadian Firms. Journal of Business Ethics. 2009, Vol. 89, No. 3, pp. 409-422. ISSN 0167-4544. DOI: 10.1007/s10551-008-0007-7.

[62] MARGOLIS, J.D., WALSH, J.P. Misery loves companies: Rethinking social initiatives by business. Administrative Science Quarterly. 2003, Vol. 48, No. 2, pp. 268-305. ISSN 00018392. DOI: $10.2307 / 3556659$.

[63] MCDONALD, L.M., HUNG LAI, C. Impact of corporate social responsibility initiatives on Taiwanese banking customers. International Journal of Bank Marketing. 2011, Vol. 29, No. 1, pp. 50-63. ISSN 0265-2323. DOI: 10.1108/02652321111101374.

[64] MCDONALD, L.M., RUNDLE-THIELE, S. Corporate social responsibility and bank customer satisfaction. International Journal of Bank Marketing. 2008, Vol. 26, No. 3, pp. 170-182. ISSN 0265-2323. DOI: $10.1108 / 02652320810864643$. 
[65] MENASSA, E. Corporate social responsibility: An exploratory study of the quality and extent of social disclosures by Lebanese commercial banks. Journal of Applied Accounting Research. 2010, Vol. 11, Iss. 1, pp. 4-23. ISSN 0967-5426. DOI: 10.1108/09675421011050009.

[66] MULKI, J.P., JARAMILLO, F. Ethical reputation and value received: customer perceptions. International Journal of Bank Marketing.2011, Vol.29, No.5, pp.358-372.ISSN 0265-2323. DOI: 10.1108/02652321111152891. [67] MULLER, A., KOLK, A. Extrinsic and Intrinsic Drivers of Corporate Social Performance: Evidence from Foreign and Domestic Firms in Mexico. Journal of Management Studies. 2010, Vol. 47, No. 1, pp. 1-26. ISSN 0022-2380. DOI: 10.1111/j.1467-6486.2009.00855.x.

[68] NATALE, S.M., SORA, S.A. Ethics in strategic thinking: business processes and the global market collapse. Journal of Business Ethics. 2009, Vol. 94, No. 3, pp. 309-316. ISSN 0167-4544. DOI: 10.1007/s10551-009-0270-2.

[69] OH, W.Y., CHANG, Y.K., MARTYNOV, A. The Effect of Ownership Structure on Corporate Social Responsibility: Empirical Evidence from Korea. Journal of Business Ethics. 2011, Vol. 104, No. 2, pp. 283-297. ISSN 0167-4544. DOI: 10.1007/s10551-011-0912-z.

[70] ORLITZKY, M. Institutional Logics in the Study of Organizations: The Social Construction of the Relationship between Corporate Social and Financial Performance. Business Ethics Quarterly. 2011, Vol. 21, No. 3, pp. 409-444. ISSN 1052-150X. DOI: 10.5840/beq201121325. [71] PAVA, M.L., KRAUSZ, J. The Association Between Corporate Social-Responsibility and Financial Performance: The Paradox of Social Cost. Journal of Business Ethics. 1996, Vol. 15 , No. 3, pp. 321-357. ISSN 0167-4544. DOI: 10.1007/BF00382958.

[72] PETERSON, R.T., HERMANS, C.M. The communications of social responsibility by US banks. International Journal of Bank Marketing. 2004, Vol. 22, No. 3, pp. 199-211. ISSN 02652323. DOI: $10.1108 / 02652320410530313$.

[73] POOLTHONG, Y., MANDHACHITARA, R. Customer expectations of CSR, perceived service quality and brand effect in Thai retail banking. International Journal of BankMarketing. 2009, Vol. 27, No. 6, pp. 408-427. ISSN 02652323. DOI: $10.1108 / 02652320910988302$.

[74] QU, R. Effects of Government Regulations, Market Orientation and Ownership Structure on Corporate Social Responsibility in China: An Empirical Study. International Journal of Management. 2007, Vol. 24, No. 3, pp. 582-591. ISSN 0813-0183.

[75] REINHARDT, F.L., STAVINS, R.A. Corporate social responsibility, business strategy, and the environment. Oxford Review of Economic Policy. 2010, Vol. 26, No. 2, pp.164-181. ISSN 0266-903X. DOI: 10.1093/ oxrep/grq008.

[76] REINIG, C.J., TILT, C.A. Corporate Social Responsibility Issues in Media Releases: A Stakeholder Analysis of Australian banks. Issues in Social and Environmental Accounting. 2008, Vol. 2, No. 2, pp. 176-197. ISSN 19780591.

[77] RENNEBOOG, L., TER HORST, J., ZHANG, C. Socially responsible investments: Institutional aspects, performance, and investor behaviour. Journal of Banking and Finance. 2008, Vol. 32, No. 9, pp. 1723-1742. ISSN 03784266. DOI: 10.1016/j.jbankfin.2007.12.039.

[78] ROUF, A. The Corporate Social responsibility Disclosure: A Study of Listed Companies in Bangladesh. Business and Economics Research Journal. 2011, Vol. 2, No. 3, pp. 19-32. ISSN 1309-2448.

[79] RUF, B.M., et al. An Empirical Investigation of the Relationship Between Change in Corporate Social Performance and Financial Performance: A Stakeholder Theory Perspective. Journal of Business Ethics. 2001, Vol. 32, No. 2, pp. 143-156. ISSN 0167-4544. DOI: 10.1023/A:1010786912118.

[80] RUNDLE-THIELE, S., BALL, K., GILLESPIE, M. Raising the bar: from corporate social responsibility to corporate social performance. Journal of Consumer Marketing. 2008, Vol. 25, No. 4, pp. 245-253. ISSN 07363761. DOI: $10.1108 / 07363760810882434$.

[81] SCHOLTENS, B. Corporate Social Responsibility in the International Banking Industry. Journal of Business Ethics. 2009, Vol. 86 , No. 2, pp. 159-175. ISSN 0167-4544. DOI: 10.1007/s10551-008-9841-x.

[82] SCOTT, A. Consumers praise privacy policies. The Internal Auditor. 2001, Vol. 58, No. 6, pp. 14-15. ISSN 0020-5745.

[83] SEMRÁDOVÁ, I. Ethical aspects of corporate culture. E+M Ekonomie a Management. 2009, Vol. 12, No. 4, pp. 69-76. ISSN 1212-3609.

[84] SIMPSON, W.G., KOHERS, T. The Link Between Corporate Social and Financial Performance: Evidence from the Banking 
Industry. Journal of Business Ethics. 2002, Vol. 35, No. 2, pp. 97-109. ISSN 0167-4544. DOI: 10.1023/A:1013082525900.

[85] SMITH, N.C. Corporate Social Responsibility: Whether or How? California Management Review.2003, Vol.45, No.4, pp.5276. ISSN 0008-1256. DOI: $10.2307 / 41166188$.

[86] SNOY, B. Ethical Issues in International Lending. Joumal of Business Ethics. 1989, Vol. 8, No. 8, pp. 635-639. ISSN 0167-4544. DOI: 10.1007/BF00383032.

[87] STANWICK, P.A., STANWICK, S.D. The Relationship Between Corporate Social Performance, and Organizational Size, Financial Performance, and Environmental Performance: An Empirical Examination. Journal of Business Ethics. 1998, Vol. 17, No. 2, pp. 195-204. ISSN 0167-4544. DOI: 10.1023/A:1005784421547.

[88] SUZUKI, K., TANIMOTO, K., KOKKO, A. Does foreign investment matter? Effects of foreign investment on the institutionalization of corporate social responsibility by Japanese firms. Asian Business and Management. 2010, Vol. 9, No. 3, pp. 379-400. ISSN 1472-4782. DOI: $10.1057 / a b m .2010 .19$.

[89] TAFRA-VLAHOVIC, M. Conceptual Frame of Corporate Social Responsibility. Medianali. 2009, Vol. 3, No. 5, pp. 163-184. ISSN 1846436X.

[90] TANKOVIC, M., MATESIC, M. Achievement of competitive advantage through implementation of sustainable development. Acta Turistica Nova. 2009, Vol. 3, No. 1, pp. 7385. ISSN 1846-4394.

[91] TEWARI, R. Communicating Corporate Social Responsibility in Annual Reports: A Comparative Study of Indian Companies \& Multi-National Corporations. Journal of Management and Public Policy. 2011, Vol. 2, No. 2, pp. 22-51. ISSN 0976-013X.

[92] UDAYASANKAR, K. Corporate Social Responsibility and Firm Size. Journal of Business Ethics. 2008, Vol. 83, No. 2, pp. 167175. ISSN 0167-4544. DOI: 10.1007/s10551007-9609-8.

[93] ULLMANN, A.A. Data in search of a theory: A critical examination of the relationships among social performance, social disclosure, and economic performance. Academy of Management Review. 1985, Vol. 10, No. 3, pp. 540-557. ISSN 0363-7425. DOI: 10.5465/ AMR.1985.4278989.
[94] VITEZIC, N. Corporate Reputation and Social Responsibility: An Analysis of Large Companies in Croatia. International Business and Economics Research Journal. 2011, Vol. 10, No. 8, pp. 85-95. ISSN 1535-0754.

[95] VAN BEURDEN, P., GOSSLING, T. The Worth of Values - A Literature Review on the Relation Between Corporate Social and Financial Performance. Journal of Business Ethics. 2008, Vol. 82, No. 2, pp. 407-424. ISSN 0167-4544. DOI: 10.1007/s10551-008-9894-x.

[96] WADDOCK, S.A., GRAVES, S.B. The corporate social performance-financial performance link. Strategic Management Journal. 1997, Vol. 18, No. 4, pp. 303319. ISSN 0143-2095. DOI: 10.1002/ (SICI)1097-0266(199704)18:4<303::AIDSMJ869>3.0.CO;2-G.

[97] WOLFE, R. The use of content analysis to assess corporate social responsibility. In: POST, J.E., FREDERICK, W.C., COLLINS, D. Research in Corporate Social Performance and Policy. Vol. 12. Greenwich, CT: JAI Press, 1991. pp. 281-308. ISBN 1559381167.

[98] WU, M-L. Corporate Social Performance, Corporate Financial Performance, and Firm Size: A Meta-Analysis. The Journal of American Academy of Business. 2006, Vol. 8, No. 1, pp. 163-171. ISSN 1540-1200.

[99] ZAHRA, S.A., OVIATT, B.M., MINYARD, K. Effects of corporate ownership and board structure on corporate social responsibility and financial performance [online]. In: Academy of ManagementBest PaperProceedings. Academy of Management Annual Meeting, Academy of Management, 1993 [cit. 2011-11-22]. pp. 336340. Available from: http://web.ebscohost.com/ ehost/pdfviewer/pdfviewer?sid=d3a6fe8d-5a8d4e31-b565-3035d65efe71\%40sessionmgr111\& vid $=1$ \&hid $=110$.

Ana Ivanisevic Hernaus, PhD University of Zagreb Faculty of Economics and Business Department of Finance aivanisevic@efzg.hr

\section{Alen Stojanovic, PhD} University of Zagreb

Faculty of Economics and Business Department of Finance alen.stojanovic@efzg.hr 


\section{Abstract}

\section{DETERMINANTS OF BANK SOCIAL RESPONSIBILITY: CASE OF CROATIA}

\section{Ana Ivanisevic Hernaus, Alen Stojanovic}

Recently financial sector and its responsibilities have come under great scrutiny. This has led to putting more emphasis on social responsibility of financial institutions, primarily banks, due to their powerful and influential position. Banks have an impact not only on financial and economic system, but on a wider community as well. Their socially responsible practices in particular may have important social implications, what is even more emphasized within bank-centric financial systems, typical of CEE countries. Due to a lack of existing research, the aim of the paper is to assess social responsibility of banks at individual and industry level in a specific CEE context. At bank individual level, focus is put on factors of bank size, ownership status and financial performance, while at the bank industry level the structure of granted loans is included in the analysis. The framework for assessing bank social responsibility is derived and adapted from previous research conducted by Cuesta-Gonzalez, et al. [23] and Scholtens [81]. It is applied to Croatian banking sector, while the level of social responsibility is empirically related to factors at bank individual and industry level.

Research findings offer an overview of social responsibility of Croatian banks. The results demonstrate that bank social responsibility is related to factors of bank size and ownership status at the individual level, and to the structure of granted loans at the industry level. However, the nature of the link between bank social and financial performance did not prove significant. Such findings offer a wider lesson of what factors are associated with social performance of financial sector. Additionally, they may serve as a useful reference point for further investigation of socially responsible practices in Croatia and other CEE countries.

Key Words: Banks, social responsibility, Croatia.

JEL Classification: G21, M14.

DOI: $10.15240 / t u l / 001 / 2015-2-009$ 